\title{
Mortgage Market Design
}

\section{Citation}

Campbell, John Y. Forthcoming. Mortgage market design. Review of Finance.

\section{Published Version}

doi:10.1093/rof/rfs030

\section{Permanent link}

http://nrs.harvard.edu/urn-3:HUL.InstRepos:9887618

\section{Terms of Use}

This article was downloaded from Harvard University's DASH repository, and is made available under the terms and conditions applicable to Open Access Policy Articles, as set forth at http:// nrs.harvard.edu/urn-3:HUL.InstRepos:dash.current.terms-of-use\#OAP

\section{Share Your Story}

The Harvard community has made this article openly available.

Please share how this access benefits you. Submit a story.

\section{Accessibility}




\title{
Mortgage Market Design
}

\author{
John Y. Campbell ${ }^{1}$
}

This version: August 2012

First draft: January 2012

\footnotetext{
${ }^{1}$ Department of Economics, Littauer Center, Harvard University, Cambridge MA 02138, and NBER. Email john_campbell@harvard.edu. Phone 617-496-6448. This paper is based on a keynote address to the annual meeting of the European Finance Association, delivered in Stockholm, Sweden on August 19, 2011. I am grateful to Tom Powers for able research assistance, and to an anonymous referee, Joao Cocco, Andreas Fuster, Stefano Giglio, Robert Hall, Howell Jackson, Anton Korinek, Parag Pathak, James Poterba, Tarun Ramadorai, Ulrich Seubert, Neil Shephard, Robert Shiller, and Arjen Siegmann for comments on earlier drafts.
} 


\begin{abstract}
This paper explores the causes and consequences of cross-country variation in mortgage market structure. It draws on insights from several fields: urban economics, asset pricing, behavioral finance, financial intermediation, and macroeconomics. It discusses lessons from the credit boom, the challenges of mortgage modification in the aftermath of the boom, consumer financial protection, and alternative mortgage forms and funding models. The paper argues that the US has much to learn from mortgage finance in other countries, and specifically from the Danish implementation of the European covered bonds system.
\end{abstract}

JEL classification: G21, R21, R31. 


\section{Introduction}

Residential mortgages are of first-order importance for households, for financial institutions, and for macroeconomic stability. The typical household in a developed economy has one dominant asset - a house - and one dominant liability - a mortgage. Mortgages are a major fraction of bank assets, despite financial innovations that allow banks to securitize mortgage pools. And the financial crisis that began in 2007 has made it abundantly clear that problems in mortgage lending have the potential to destabilize the financial system and the economy.

Despite their importance, mortgages have traditionally been a specialty topic in finance, and most mortgage research has been published in real estate and housing finance journals, not general-interest finance or economics journals. In this paper I argue that to understand mortgage markets we need a much broader perspective that integrates insights from across our discipline: not only from fields within finance such as asset pricing, behavioral finance, and financial intermediation, but also from urban economics and macroeconomics. Each of these fields can be compared to the proverbial blind man groping an elephant, accurately recording one aspect of the phenomenon but unable to perceive the whole. Here I attempt a sketch of the whole elephant.

There is striking variation in mortgage market structure across countries. An obvious question is whether this variation has deep fundamental causes or is the result of historical accident. To the extent that not all cross-country differences are attributable to different circumstances, it may be possible to identify best practices in mortgage markets and transfer them from one country to another. A theme of this paper is that the United States, in particular, has much to learn from practices in certain parts of Europe.

To set the stage, I graphically summarize key properties of mortgage markets in a range of developed countries. Figure 1 plots the ratio of residential mortgage debt to GDP in 2009 against the homeownership rate (the fraction of properties that are owner-occupied in the most recently available data from each country), for sixteen developed countries studied by the International Monetary Fund (IMF 2011). The United States is middle-of-the-road in both respects. The lowest homeownership rates are in northern European countries, particularly Germany whose homeownership rate is only $43 \%$, while the highest rates are

in southern European countries such as Greece, Italy, and Spain with about $80 \%$ homeownership. The lowest level of mortgage debt (22\% of GDP) is in Italy, while the highest levels (above 100\% of GDP) are in Denmark and the Netherlands. It may at first seem surprising that homeownership rates are not positively correlated with levels of mortgage debt; this reflects cross-country variation in house prices, patterns of homeownership (with many southern European homes owned either by foreigners or by locals who own rural homes and rent urban apartments), and reliance on family and life-cycle savings to finance homeownership. 
Although the US has roughly average levels of homeownership (67\%) and mortgage debt ( $72 \%$ of GDP), it is unusual in two other respects. Figure 2 plots the average number of years that a mortgage carries a fixed rate. The lowest values (around 1 year) are in southern European countries such as Portugal, Spain, and Italy, where adjustable-rate mortgages predominate. The UK and Ireland similarly rely heavily on adjustable-rate mortgages. The average fixed-rate period is 5 years in Canada, 7-10 years in Belgium, France, and Germany, almost 20 years in Denmark, and 27 years in the US reflecting a roughly $90 \%$ market share for 30-year nominal fixed-rate mortgages. These instruments, which are taken for granted in the US, are anomalous within the global mortgage system. The dominance of long-term fixed-rate mortgages in the US is likely the result both of a relatively stable inflation history, and of public policy promoting these mortgages.

Figure 3 plots an index of government participation in housing finance, constructed by the IMF (2011), against the homeownership rate. The IMF index combines information on subsidies to home purchases, government funding or guarantees for mortgage loans, preferential tax treatment for mortgage interest or capital gains on housing, and the existence of a dominant state-owned mortgage lender. The figure shows that US housing policy is highly interventionist, more so than any other country illustrated except Singapore. The high value of the government participation index for the US results from subsidies to low and middle income homebuyers, subsidized mortgage guarantees by the government sponsored entities (GSEs), and favorable tax treatment of mortgage borrowing and housing capital gains. The main stated goal of much US housing policy is to increase the homeownership rate, but as previously noted the US has only average homeownership, and more generally there is only a very weak positive cross-country correlation between housing market intervention and homeownership. ${ }^{2}$

The remainder of this paper summarizes the literature on mortgages within specific subfields. In section 2 I begin with urban economics, a field that emphasizes externalities from homeownership and from mortgage foreclosures. Such externalities provide an important rationale for public policy towards mortgages. In section 3 I present insights from asset pricing, which regards mortgages as ways to share risks between borrowers and lenders. From this point of view, mortgage defaults and foreclosures are merely another way to allocate risks. Section 4 turns to behavioral finance, a field that takes seriously variation across households in personal circumstances (such as the propensity to move) and financial sophistication. Behavioral finance can also be used to justify consumer financial protection in mortgage markets.

Mortgage loans need to be funded, and the problem of assuring a reliable supply of capital for mortgage lending is a topic in financial intermediation. I review insights from this field in section 5. Finally, mortgage markets are influenced by macroeconomic conditions, for example inflation volatility, and problems in mortgage markets have an important influence

\footnotetext{
${ }^{2}$ Warnock and Warnock (2008) present a detailed cross-country empirical analysis of housing finance systems, arguing that legal rights, credit information, and macroeconomic stability all encourage the development of housing finance.
} 
on monetary policy and macroeconomic stability. I consider macroeconomic aspects of mortgages in section 6 .

Section 7 combines these insights to evaluate the current state of the US mortgage system, and options for reform. Section 8 briefly concludes. I argue that there is a legitimate public interest in a stable, efficient mortgage system and that this is a propitious moment to experiment with mortgage market design, not only through importing design features from other successful mortgage markets, but also by considering innovations that have been suggested by financial economists. Although our theoretical understanding of mortgage markets is still weak relative to the theory that underpins classic applications of market design (to auctions and matching problems, for example), financial theory and theoretically grounded empirical research will be important for this enterprise. Thus mortgage research offers financial economists an exciting opportunity to contribute to the well-being of society.

\section{Urban Economics}

An important theme of urban economics is that household decisions about the location, ownership, and financing of their residence can have spillover effects on other households in the same community. These spillover effects are hard to measure and hard for society to handle through the assignment of property rights. Accordingly there may be geographical externalities that justify policy interventions.

Traditionally, US politicians have emphasized positive externalities from homeownership, pointing to the fact that homeowners have a greater incentive than renters to take uncompensated actions that benefit the community. There is indeed some evidence of stronger civic engagement among homeowners (DiPasquale and Glaeser 1999, Jaffee and Quigley 2011), although this could just reflect a greater value placed on homeownership by civically minded people and does not prove that policies to increase homeownership strengthen civic engagement. Also, there are countervailing negative environmental externalities arising from the dispersed and energy-intensive nature of owner-occupied housing (Glaeser 2011). Nonetheless the positive view of homeownership has typically prevailed and has been used to justify government involvement in the housing finance system.

\section{Fragile housing}

Here I focus on a different type of externality arising from the fragile nature of singlefamily housing. Houses need diligent maintenance and are vulnerable to vandalism. Owner occupancy is the dominant form of ownership for single-family houses because owner occupants have an incentive to maintain and protect their houses and can do so at lower cost than absentee owners.

When an owner occupant becomes financially distressed, the incentive system no longer 
works so well. A distressed homeowner may neglect her property because she fears losing it to the mortgage lender in a foreclosure - in which case the mortgage lender will reap the benefit of maintenance expenditures - or because she is tightly borrowing constrained and effectively discounts the future benefits of maintenance at a high rate (Melzer 2011). If foreclosure does occur, the mortgage lender faces the challenges of absentee ownership until it can sell the house to a new owner occupant. These challenges are particularly severe in bad neighborhoods where vacant properties may be vandalized, and where fixed costs of protecting houses are large relative to property values.

Campbell et al. (2011a), using Massachusetts data from the 1980s through 2009, compare the prices of houses sold by mortgage lenders after foreclosure with the prices of comparable properties sold by owner occupants, and find an average foreclosure discount of $27 \%$. The discount is larger for cheaper houses in neighborhoods with low house prices, suggesting the relevance of vandalism and the costs of protecting against it.

\section{Foreclosure spillovers}

While these costs of foreclosure are borne by mortgage lenders, and thus will be reflected in the structure and pricing of mortgage contracts, Campbell et al. also present evidence that foreclosures have negative spillover effects on the pricing of neighboring properties. Spillover effects are hard to prove conclusively, because negative shocks to the health of a local economy will both lower house prices and increase foreclosures in an area, even if there is no causal linkage from foreclosures to house prices. To get around this problem, Campbell et al. argue that local economic shocks should not have differential effects within a small area such as a circle with a radius of a quarter-mile. They also argue that reverse causality from house prices to foreclosures will show up in house price declines that precede foreclosures rather than following them.

Accordingly, Campbell et al. use a difference-in-difference methodology, showing that a distance-weighted index of recent foreclosures within 0.1 mile of a house sale predicts the sale price negatively, after controlling for foreclosures within a quarter mile, and more so than an index of future foreclosures within 0.1 mile. Their preferred estimate of the causal spillover effect is that a typical nearby foreclosure lowers the price of a house by about $1 \%$. This effect, like the direct value loss in foreclosure, is stronger in low-priced neighborhoods, and it appears to be long-lasting because it remains significant even after lagging the foreclosure index by a year. These empirical patterns once again suggest that vandalism and crime are involved in the negative externality from foreclosures. Immergluck and Smith (2006) and Ellen et al. (2011) present direct evidence linking local criminal activity with foreclosures. ${ }^{3}$

Negative spillovers from foreclosures are particularly destructive in circumstances where house prices are already depressed, because then falling house prices readily stimulate more

\footnotetext{
${ }^{3}$ Lin et al. (2009) emphasize another channel for the spillover effect: foreclosed houses sold at depressed prices are used as comparables by real estate brokers and appraisers. See also Anenberg and Kung (2012) and Gerardi et al. (2012).
} 
defaults and foreclosures, which drive down prices further. This mechanism appears to have been operative in the US during the Great Depression. In the late 1920s, US mortgages were often short-term balloon loans that required frequent refinancing. Low house prices and reduced bank lending capacity in the early 1930s prevented many homeowners from refinancing, causing a wave of foreclosures that exacerbated the Depression. This experience was an important motivation for the widespread adoption of long-term amortizing fixed-rate nominal mortgages which have dominated the US mortgage market for the past 70 years. ${ }^{4}$

More recently, the fear of a foreclosure spiral has motivated the Obama Administration's programs to modify mortgage terms for borrowers with negative home equity. In 2009 the administration justified its Making Home Affordable plan as follows: "In the absence of decisive action, we risk an intensifying spiral in which lenders foreclose, pushing area home prices still lower, reducing the value of household savings, and making it harder for all families to refinance. In some studies, foreclosure on a home has been found to reduce the prices of nearby homes by as much as 9 percent" (US Treasury 2009). ${ }^{5}$

\section{Asset Pricing}

Asset pricing economists view mortgages as contracts that share various types of risk between mortgage lenders and borrowers. Long-term mortgages protect borrowers against deteriorations in their own creditworthiness or in credit market conditions. That is, borrowers with existing mortgages are not required to put up more collateral if they enter financial distress, or if the standards for underwriting new mortgages become tighter. These protections are taken for granted by mortgage and other retail borrowers, but they do not exist in other types of collateralized borrowing used by corporations and financial institutions, such as repurchase agreements. Presumably the reason has to do with the often limited access of mortgage borrowers to unsecured credit markets, and the high costs of foreclosures as documented in the previous section.

\section{FRMs and $A R M s$}

Even when lenders bear the risks of changing borrower circumstances and credit market conditions, there remain numerous questions about the distribution of other risks, specifically real interest rate, inflation, and house price risks. To understand how different mortgages can allocate these risks differently, consider two simple cases: a nominal fixed-rate mortgage

\footnotetext{
${ }^{4}$ Amortizing fixed-rate mortgages did exist before the Great Depression, and were particularly favored by savings and loans institutions which had a large market share in mortgage origination (Morton 1956, Chapter 2). However, average maturities were considerably shorter than they are today (Grebler, Blank, and Winnick 1956, Chapter 15).

${ }^{5}$ There is also the possibility that foreclosures encourage neighbors to default, not by lowering their house prices but through a direct mechanism such as learning or a reduction of the stigma associated with default (Goodstein et al. 2011).
} 
(FRM) and a nominal adjustable-rate mortgage (ARM).

A standard FRM has a level path of nominal payments designed to pay off the principal balance as well as interest over the life of the mortgage. The stream of payments is invariant to changes in the level of real interest rates, and in this sense the borrower is protected against real interest rate shocks (although of course the present discounted value of the payments, the market value of the liability, does vary with real interest rates).

The main uncertainty that affects a nominal FRM borrower concerns the inflation rate over the life of the mortgage. If inflation accelerates, the real value of the payments declines rapidly and the borrower benefits in real terms while the lender suffers. This was the situation in the US during the late 1960s and 1970s. If inflation decelerates, or in the extreme if the economy experiences deflation, then the outcome depends on prepayment penalties and house prices. If there are no prepayment penalties, as is normally the case in the US, and if nominal house prices are sufficiently high, then borrowers can refinance their nominal FRMs to lower rates and they do not suffer from low inflation. However if there are prepayment penalties, as is typical in Germany, or if nominal house prices decline to a level that prevents refinancing, then FRM borrowers are required to make higher real payments as inflation declines.

The initial mortgage rate compensates lenders for the balance of risks that they bear. With volatile inflation and low prepayment penalties, nominal FRMs are one-sided bets on inflation and become extremely expensive in equilibrium.

A standard ARM requires a borrower to pay a floating nominal interest rate, indexed to the general level of short-term interest rates, together with small additional payments to amortize the principal balance. In practice, ARMs often have especially low initial rates ("teaser rates"), but for now consider a plain-vanilla ARM without any teaser period. This mortgage is a floating-rate note with a relatively stable real market value (since short-term uncertainty about inflation is small, so most inflation shocks are compensated by variation in the nominal interest rate). However, the stream of payments is subject to significant uncertainty.

If real interest rates increase, then required payments also increase although their present value does not. If inflation increases, then the timing of the payment stream changes, with higher real payments early in the life of the mortgage (the result of higher short-term nominal interest rates), and lower real payments later once inflation has eroded the real value of the mortgage principal. A mortgage borrower with unused borrowing capacity can compensate for the increase in early payments by borrowing to finance them, repaying the additional loan with the additional real income available later in the life of the mortgage. A mortgage borrower who is constrained, however, faces significant risk to consumption from the uncertainty about the timing of repayment implied by an ARM. Campbell and Cocco (2003) refer to this as "income risk" and contrast it with the "wealth risk" that inflation creates for an FRM borrower. 
Because the term structure of interest rates is normally upward sloping, both the initial payments and the expected stream of future payments are normally lower for an ARM than for a FRM. For this reason, binding current borrowing constraints tend to lead mortgage borrowers to prefer ARMs. However, the anticipation of future borrowing constraints makes ARMs risky and may lead borrowers to prefer FRMs. Overall, the preference for ARMs should be greatest among mortgage borrowers with rapidly increasing income who are buying large houses relative to their current income. Campbell and Cocco (2003) develop an optimizing life-cycle model of mortgage choice with these predictions, and Johnson and Li (2011) present evidence that ARM borrowers tend to be currently borrowing-constrained.

Both the yield spread between short- and long-term bonds and the rational expectation of future excess returns on long bonds vary over time. These two variables are positively but not perfectly correlated. If the risk preferences and personal circumstances of mortgage borrowers have a cross-sectional distribution that is unchanged over time, rational borrowers with binding constraints are more likely to choose ARMs when the yield curve is steep, to minimize initial payments, while other borrowers should shift to ARMs when the rational expectation of long bond returns is high. Campbell and Cocco (2003) emphasize the former effect, while Koijen et al. (2009) argue that the latter explains much of the time-variation in the market share of ARMs in US data.

\section{Default}

The analysis above considers the possibility of refinancing a mortgage but not the possibility of default. However, the current housing downturn has brought default to the center of the mortgage literature.

The attractiveness of default to a borrower should vary with "recourse", the ability of the mortgage lender to pursue a defaulted borrower for the balance of the mortgage after foreclosing on the house. Most European countries have recourse mortgages, as do most US states with some important exceptions including California. In the US, the practical impact of recourse varies across states (with details of state law) and over time (with the federal law governing personal bankruptcy, which can be used to escape recourse). It appears that US mortgage lenders are less likely to pursue borrowers, even in recourse states, than are European mortgage lenders. However Ghent and Kudlyak (2011) compare default rates across US states and find lower default rates in recourse states, particularly for higherpriced homes whose owners are likely to have other financial resources that can be seized by mortgage lenders.

Even without recourse, default imposes some costs on the borrower: at a minimum, the cost of moving and damage to the borrower's credit score. ${ }^{6}$ A defaulted borrower will have little access to credit for a period of time, making it difficult to buy another house and forcing a period of rental occupancy. These costs imply that borrowers should not default

\footnotetext{
${ }^{6}$ Guiso et al. (2009) emphasize that default imposes additional psychic costs on borrowers who regard default as immoral or shameful.
} 
if they have positive home equity (since in this case they can sell the house and pay off the mortgage without incurring default costs), and even with negative home equity should not default until negative home equity becomes sufficiently large. Default is the exercise of a "real option" (Deng et al. 2000), and thus the trigger level of negative home equity should depend not only on default costs but also on the stochastic process for house prices. Specifically, high expected price growth and high volatility of price shocks should both delay default by increasing the trigger level of negative home equity.

Borrowing constraints are also highly relevant for the default decision. As borrowing constraints bind, they increase the marginal utility of consumption today relative to future marginal utility, and thus increase the effective rate at which households discount the future. Since default has immediate benefits (the cessation of burdensome mortgage payments) and some delayed costs, it will be more attractive when borrowing constraints are binding. That is, borrowing constraints accelerate default by decreasing the trigger level of negative home equity. ${ }^{7}$ Foote et al. (2008) present a two-period model and Campbell and Cocco (2012) calibrate a multi-period life-cycle model of these effects.

This theoretical framework implies that negative home equity is a necessary but not a sufficient condition for mortgage default. At low levels of negative home equity, only financially distressed borrowers with depleted assets and low income - perhaps the result of unemployment - will default. As house prices fall, more borrowers will reach the level of negative home equity that triggers default, and in the extreme, all borrowers will strategically default. Campbell and Cocco (2012) verify this pattern in simulated data with rational borrowers. They find that at modest levels of negative home equity, default rates are low and defaulters are more distressed than non-defaulters in the sense that their mortgage payments are larger relative to their current income. At higher levels of negative home equity, default rates increase and the difference in financial distress between defaulters and non-defaulters disappears.

Bajari et al. (2008), Bhutta et al. (2010), Elul et al. (2010), and Foote et al. (2008) find patterns consistent with these predictions in recent US data. Li et al. (2010) argue that the reform of the US bankruptcy code in 2005 made it harder for borrowers to escape non-housing debt through bankruptcy; by tightening constraints on indebted borrowers, the bankruptcy reform decreased the trigger level of negative home equity and increased defaults in the late 2000s. ${ }^{8}$

Campbell and Cocco (2012) also use their model to compare the default patterns generated by FRMs and ARMs. They find comparable overall levels of defaults for these two mortgage types, but these defaults occur in different circumstances. While both types of

\footnotetext{
${ }^{7}$ The practitioner literature discusses a "dual-trigger" model of default, in which both negative home equity and financial distress are required for default. It is more accurate to think of a single negative-equity trigger whose location is influenced by financial distress.

${ }^{8}$ Mitman (2011) presents a theoretical analysis of the interaction between the bankruptcy code and mortgage default that predicts this effect.
} 
mortgages generate high default rates if house prices decline far enough, in states of the world with modest levels of negative home equity, FRM defaults occur when interest rates are low (since old FRMs are expensive relative to rental housing), whereas ARM defaults occur when interest rates are high (since their required payments increase). FRMs are also somewhat more likely to generate default waves, as idiosyncratic income shocks are less important drivers of default for FRM borrowers so their default decisions tend to be more highly correlated.

To summarize, the possibility of default shifts the balance of risks in a mortgage contract. Lenders bear the risk of extremely low house prices, because borrowers with non-recourse mortgages effectively have a put option on their house. The default option also caps the potential gains to lenders from favorable interest rate movements in states of the world with moderately low house prices. Naturally these risks are also priced into mortgage interest rates, which will be higher when lenders believe that default is likely or that default tends to occur in bad states of the world with high marginal utility of wealth.

\section{Behavioral Finance}

Behavioral finance confronts the fact that borrowers vary in their personal circumstances, and in their ability to manage their financial affairs in their own long-run interest. Three particularly important types of heterogeneity are in moving propensity, financial sophistication, and present-biased preferences.

\section{Moving propensity}

There is nothing irrational, of course, about moving from one house to another. But non-economic considerations are often important motivations for moves, so it is natural to classify the desire to move as a behavioral influence on the mortgage market.

With limited exceptions, mortgages in the US are not assumable. That is, a mortgage collateralized by a specific house cannot be transferred by a departing homeowner to the new owner of the house. Instead, the departing homeowner must pay off the old mortgage and the new owner must obtain a new mortgage. This fact implies that moves have economic consequences when existing mortgages are more advantageous to borrowers than are new mortgages.

Such discrepancies between the terms of old and new mortgages are unimportant for plain-vanilla ARMs, but can be very significant for FRMs in an environment of rising interest rates that makes old FRMs cheaper than new ones. In such an environment movers suffer relative to continuing homeowners, if movers are forced to prepay their mortgages at face value and refinance at a higher rate.

The asymmetric treatment of movers and continuing homeowners in FRM systems is im- 
portant for several reasons. First, to the extent that moves are random events for households (forced by job changes or other exogenous life events), FRM systems create idiosyncratic economic risks that are difficult to insure and affect household welfare ex ante.

Second, uncertainty about the aggregate moving propensity of households is one important determinant of prepayment risk, a major factor in pricing mortgage-backed securities. FRM borrowers have an incentive to avoid moving when interest rates rise, but the magnitude of this "lock-in" effect can be hard for investors to estimate.

Third, asymmetry of information about the moving propensity of individual households can influence the structure of the mortgage market. Mortgage lenders have incentives to separate borrowers by their moving propensity, for example by offering lower interest rates in exchange for an up-front fee or "points" in US terminology (Brueckner 1994, Stanton and Wallace 1998). To the extent that some market participants have more information than others about the moving propensity of borrowers, mortgage-backed securities markets may become illiquid as investors fear trading with counterparties who may be better informed.

A unique feature of the Danish mortgage system, which has traditionally been dominated by FRMs, is that it avoids treating movers and continuing homeowners asymmetrically. Borrowers are allowed to prepay their mortgages at face value without penalty, as in the US system; but they can also extinguish their mortgage debt by buying mortgage bonds, which is economically equivalent to buying back their mortgages at market value. This avoids the lock-in effect in an environment of rising interest rates. In addition, Danish mortgages are typically assumable so that new homeowners can take on mortgages from movers.

\section{Financial sophistication}

A great variety of mortgages are available, some of which have complex features that are difficult even for financial professionals to thoroughly understand. Mortgage costs appear in a number of forms, not all of which are straightforward to measure. Households take out mortgages relatively infrequently, and often negotiate them at the same time that they are undergoing a major life transition by moving homes. Under these circumstances it is not surprising that households, particularly those with less financial sophistication, sometimes make decisions that appear to be suboptimal.

There is some direct evidence that mortgage borrowers fail to understand the terms of their mortgages. Campbell (2006) and Schwartz (2006) use the American Housing Survey (AHS) to show that some self-reported FRM rates are implausibly low given the years in which the mortgages were taken out. Such misstated rates are more common among less educated households. Bucks and Pence (2008) compare survey evidence on the adjustability of ARM rates to administrative data on ARM terms, and show that households collectively underestimate the extent to which their ARM rates can rise.

Many observers have been concerned that borrowers pay excessive fees to mortgage brokers. Woodward (2004) and Woodward and Hall (2012) show that complex mortgage terms 
are associated with higher fees paid to mortgage brokers, especially by less educated households.

The decision to refinance a FRM is challenging for many households. Campbell (2006) presents evidence that in the late 1990s and early 2000s many households, particularly poorer and less educated ones, paid higher mortgage rates than necessary. In AHS data, 12-14\% of households were paying more than 2 percentage points above the prevailing mortgage interest rate in the late 1990s and early 2000s; this figure rose above 25\% in 2003 after steep drops in interest rates made refinancing particularly advantageous. These results are unlikely to be explained by credit deterioration (proxies for which are measured in the AHS) or lack of home equity given the buoyant housing market of the period.

Refinancing is also important for borrowers with ARMs that offer low initial "teaser" rates. Such features are common in both the US and the UK, and they create an economic incentive to refinance ARMs at the end of the teaser period. Miles (2004) shows that in the early 2000s, about a third of UK borrowers had not refinanced and were paying higher "standard" rates. In the economic environment of the time, it is unlikely that more than a fraction of these borrowers were prevented from refinancing by negative home equity or income shocks; instead, this was likely a mistake by less sophisticated borrowers.

It is also possible that borrowers make mistakes when choosing between ARMs and FRMs. Campbell (2006) argues that lagged changes in long-term interest rates influence the market share of ARMs in a way that is hard to rationalize, although Koijen et al. (2009) argue that a rational model of mortgage choice fits US data well.

Mistakes by mortgage borrowers have several important implications for equilibrium in the mortgage market. Random variation in the incidence of these mistakes creates an artificial risk that must be managed by mortgage investors. It is ironic that prepayment risk, the subject of sophisticated modeling efforts by mortgage-backed security experts in the 1990 s and 2000s, is caused by consumers' inability to handle the excessively complex prepayment option built into a conventional FRM.

The profits generated by mortgage mistakes are competed away in a competitive market for mortgage origination. One effect is that originators and brokers pay high marketing costs as they compete for the business of naive mortgage borrowers. A second effect is that mortgage rates fall, so sophisticated borrowers benefit at the expense of unsophisticated ones.

Gabaix and Laibson (2006) have argued that this second effect can inhibit useful financial innovation. Consider an entrepreneur who designs and markets an automatically refinancing FRM. Such a FRM would be socially beneficial because it would eliminate the transactions costs of conventional refinancing, and would protect naive borrowers who fail to refinance conventionally at the right time. However, the new product would be more expensive for sophisticated borrowers, since it would not offer any cross-subsidy from naive borrowers. And if the entrepreneur attempted to market the new product to naive borrowers, he might 
find instead that the marketing effort converted naive borrowers into sophisticated borrowers, who would then decline to buy the product.

\section{Present-biased preferences}

Households with present-biased preferences (Laibson 1997) favor the present over the future more than they discount the near future relative to the distant future. In other words, they plan to be patient but succumb to temptation.

Khandani et al. (2009) argue that present-biased mortgage borrowers are likely to extract home equity when they refinance their mortgages, at the expense of their long-run financial wellbeing. This temptation exists in all forms of mortgages, but the nominal FRM, with its strong rational incentive to refinance in an environment of rising house prices and falling interest rates, provides frequent opportunities to succumb. On the other hand Chen et al. (2011) argue that cash-out refinancing tends to occur when local economic conditions deteriorate (so long as house prices are high enough to permit it), which is consistent with rational consumption-smoothing by homeowners. ${ }^{9}$

The same arguments apply to mortgage innovation that increases credit available to first-time homebuyers. If borrowers are rational and have time-consistent preferences, such innovation helps them smooth their consumption of goods and housing services over the life cycle (Piskorski and Tchistyi 2010, 2011). If not, the availability of additional credit may worsen the temptation to consume too much early in life (Ghent 2011).

\section{Financial Intermediation}

Mortgage loans must be funded, and this requires the involvement of financial intermediaries who originate loans and either hold them or repackage them for sale to ultimate investors. Other intermediaries may provide guarantees, insuring certain mortgage risks. Whatever risks borrowers do not bear must be allocated to originators, ultimate investors, or guarantee providers. Different mortgage systems allocate these risks differently.

The allocation of mortgage risks is important not only because it determines the distribution of gains and losses ex post and the pricing of mortgages ex ante, but also because it influences the incentives of financial intermediaries. A successful mortgage system must give intermediaries incentives to underwrite properly, gauging the credit risk of borrowers and setting mortgage rates in relation to that risk. It must also give intermediaries incentives to modify mortgages if borrowers enter financial distress and modification is in the interest of mortgage holders.

\footnotetext{
${ }^{9}$ In a similar spirit Gerardi et al. (2010) show that mortgage innovation has improved the relationship between housing choice and future income, consistent with a rational consumption-smoothing model.
} 
Mortgage systems can be classified into three main categories, which allocate risks and provide incentives in different ways. The oldest system is deposit-financed lending, in which originators hold loans and issue deposits to finance them. This system has the great merit that solvent originators have strong incentives both to underwrite mortgages carefully and, if necessary, to modify them. However, deposit-financed lending also has several serious disadvantages. First, mortgage supply tends to be limited by the local availability of deposit funding. Second, deposit-financed lending involves liquidity transformation, since deposits can be withdrawn on demand while mortgages cannot. This makes deposit-financed lenders vulnerable to bank runs, particularly in systems without government insurance of retail deposits and in cases where deposits have been attracted from wholesale money markets (the UK mortgage lender Northern Rock being a spectacular recent example). Third, deposit-financed lending usually involves an element of maturity transformation, particularly when mortgages are fixed-rate. This exposes mortgage lenders to fundamental risk from changes in interest rates. Fourth, the incentives of mortgage lenders can become misaligned if a negative fundamental shock, from a weak economy or rising interest rates, puts these intermediaries into financial distress. The most famous example of this is the US savings and loan crisis of the 1980s, in which S\&Ls, distressed after interest rates increased during the early 1980s, made risky loans in the knowledge that further losses would be covered by deposit insurance while gains would accrue to S\&L shareholders.

In the years since the S\&L crisis, the US has largely shifted to a securitized mortgage system. In this model, originators package mortgages into pools that can be sold to ultimate investors. A natural concern in such a system is that originators have better information about credit risks than mortgage investors do. To handle this, the US system has relied heavily on credit guarantees provided by the government sponsored entities (GSEs), Fannie Mae and Freddie Mac. Ultimate investors bear interest rate risk, prepayment risk, and residual credit risk for types of mortgages not covered by public guarantees. During the 1990s and 2000s, this system allowed US mortgages to become liquid assets funded by global capital markets rather than by local depositors.

The securitized system also has disadvantages that became glaringly obvious after the onset of the global financial crisis in 2007. First, if ultimate investors are ignorant about credit risk or if credit guarantees are mispriced, originators no longer have the incentives to underwrite properly. The US experience suggests that government credit guarantees are particularly hard to price correctly and are vulnerable to political distortion. Underpriced guarantees encourage originators to make excessively risky loans and pass the losses to taxpayers. Keys et al. (2010, 2012) present evidence that securitized mortgages were poorly underwritten in the mid-2000s.

Second, while in principle a securitized system does not expose mortgage originators to fundamental mortgage risks, in practice originators often hold mortgage-backed securities on their books either as inventory for their MBS distribution business or because bank capital regulation favors these investments. Thus originators can become distressed in a securitized system just as they can in the traditional deposit-financed lending system. 
Third, the problem of capital flight can also reappear in a securitized system if public credit guarantees are not fully explicit or credible. This problem afflicted the GSEs in 2007 and 2008 and ultimately forced a government takeover of these institutions.

Finally, a securitized system may not give mortgage servicers the proper incentives to modify mortgages in a housing downturn, both because servicers bear modification costs without receiving benefits, and because the ultimate owners of mortgage-backed securities may have divergent interests. The scale of this problem in the recent crisis is actively debated: Adelino et al. (2009) and Foote et al. (2010) minimize its importance, while Agarwal et al. (2011) and Piskorski et al. (2011) argue that it is serious.

The last major mortgage system, common in Europe, uses covered bonds to address some of the problems described above. Covered bonds are claims on originators but are collateralized by pools of mortgages. Importantly, the underlying mortgages remain on the books of originators, who must replenish the collateral pool when individual mortgages in the pool default. Thus originators continue to have strong incentives both to underwrite mortgages carefully and to modify them when that is in the interest of mortgage lenders. Covered bond systems permit maturity transformation (when the maturity of the bonds differs from the maturity of the underlying mortgages), and this can create problems similar to those of a deposit-financed lending system. However, in countries that have limited maturity transformation, covered bond systems have been impressively stable.

In both securitized and covered bonds systems, it is essential that financial instruments backed by mortgages trade in liquid markets. To maintain liquidity, these systems must minimize information asymmetries. Ways to do this include packaging mortgages into large, diversified pools; designing mortgages to limit their exposure to personal circumstances and behavioral uncertainties; tranching pools of mortgages to create instruments that are protected against prepayment or default; and providing public credit guarantees. Many observers have praised the Danish mortgage system, which emphasizes the first two approaches.

\section{Macroeconomics}

The form of the mortgage system has the potential to influence macroeconomic outcomes, principally by altering the transmission mechanism of monetary policy and the political constraints on the central bank. In turn, the macroeconomic history of a country has a powerful influence on its mortgage system.

Increases in interest rates have different effects on homeowners with FRMs and ARMs. The mortgage payments of FRM borrowers remain unchanged when current interest rates increase, so in a FRM system monetary policy has a direct effect only on new borrowers (although existing borrowers are of course affected by house prices and other consequences 
of monetary policy). In an ARM system, on the other hand, all existing homeowners make higher payments when interest rates increase. This can have a powerful effect on household consumption, especially if a significant fraction of homeowners are borrowing-constrained.

For the same reason, the political economy of monetary policy varies with the nature of the mortgage system. In a FRM system where mortgages are financed through maturity transformation, as in the traditional US system of deposit-financed lending, the central bank may be reluctant to raise interest rates for fear of creating financial distress among mortgage lenders. This may have been one reason for the weak Fed response to rising inflation during the 1970s. In an ARM system, on the other hand, increases in interest rates can be highly unpopular with homeowners and this may create political pressure to keep interest rates low.

ARM and FRM systems also generate different patterns of default in an environment with declining house prices. If the central bank responds to such an environment by lowering interest rates, ARM borrowers benefit from lower required mortgage payments, but FRM borrowers do not if negative home equity prevents them from refinancing their mortgages. In this respect it is unfortunate that the US, with unusually low interest rates in the recent downturn, has a predominantly fixed-rate mortgage system so that only homeowners with positive home equity can benefit from the low interest-rate environment.

On the other hand, ARM systems can generate default waves when inflationary shocks force the central bank to increase interest rates. Figure 4 illustrates two waves of financial distress experienced in the UK, where ARMs predominate. The figure plots bankruptcy orders, rather than mortgage defaults, as this series is readily available over a long period of time and positively correlated with mortgage defaults and foreclosures. The bankruptcy series spikes up in the early 1990s, shortly after an increase in inflation and nominal interest rates at the end of the 1980s that increased the required payments on ARMs. The bankruptcy series also spikes up in the late 2000 s, despite the fact that inflation and interest rates were low, because declining house prices and poor macroeconomic conditions outweighed the payment relief on ARMs at this time.

All these considerations make it awkward to run a common monetary policy in an area with heterogeneous mortgage systems. In the early 2000s, British concern about this problem was one justification for the UK to keep its own currency rather than joining the euro, and the Miles Report (2004) was originally commissioned by Chancellor Gordon Brown to study whether the UK should try to harmonize its mortgage system with those of major eurozone economies.

Conversely, the variation in mortgage systems across developed countries appears to be related to their macroeconomic history. Specifically, a history of volatile inflation is strongly associated with the use of ARMs, as shown in Figure 5. Because many of the countries included in the figure are members of the eurozone, inflation volatility is calculated over the pre-euro period of 1977-1999. A natural explanation for the pattern shown in Figure 5 is that volatile inflation makes nominal FRMs with prepayment options excessively risky for 
lenders and therefore too expensive for borrowers. ${ }^{10}$

Of course, this raises the interesting question of why mortgage systems in southern Europe have remained ARM-dominated even after the introduction of the euro. It appears that there is substantial inertia in mortgage systems, possibly resulting from the difficulty and expense of educating borrowers about mortgage contracts that may be unfamiliar to them even if common in other countries.

\section{Prospects for the US Mortgage System}

In this paper I have presented insights from five different fields - urban economics, asset pricing, behavioral finance, financial intermediation, and macroeconomics - about the operations of mortgage systems. I conclude by using these insights to discuss future prospects for the US mortgage system. In turn, I will discuss lessons from the credit boom; the challenge of modifying mortgages to reduce foreclosures; alternative forms for mortgage contracts; consumer financial protection; and finally alternatives for funding mortgage lending.

\section{Lessons from the credit boom}

The preceding analysis provides the necessary ingredients to understand recent problems in the housing market. These problems arose from a boom and subsequent collapse in both house prices and mortgage lending, and the effects of the collapse on leveraged borrowers and mortgage lenders. There is an active debate about the deeper causes of these events.

Some economists, notably Foote et al. (2012), emphasize overoptimistic expectations about the future path of house prices during the boom, and downplay institutional features of the housing finance market as being either static or changing merely in response to optimistic price expectations.

A second view is that excessive household leverage was encouraged by longstanding US policies, particularly the tax subsidy to mortgage-financed owner occupancy. Economists have long questioned the appropriateness of subsidizing leveraged homeownership in this way (Glaeser and Shapiro 2003).

A third view is that the problems had recent institutional origins in looser underwriting standards (Mayer et al. 2009) that increased the supply of mortgage lending (Mian and Sufi 2009), and in mortgage innovation during the credit boom of the early and mid 2000s. At this time many new types of mortgages appeared (Committee on the Global Financial System 2006, Scanlon et al. 2008). While terminology varies from country to country

\footnotetext{
${ }^{10} \mathrm{An}$ alternative response to a volatile inflation history is to denominate mortgages in foreign currency. During the credit boom, foreign-currency mortgages were popular in countries such as Iceland, Poland, and Russia. Domestic-currency depreciation during the financial crisis made these mortgages unaffordable for borrowers, many of whom defaulted.
} 
(frequently used terms include interest-only, hybrid, flexible, and option mortgages), the common feature of these new mortgages is that required payments are low initially - because the initial interest rate is low, and often also because principal is not initially repaid - and then payments increase discretely after a few years. Lower required payments make it possible to increase the amount borrowed if banks apply a fixed ratio of mortgage payments to income to judge mortgage affordability. Amromin et al. (2011) show that in the US market, these new mortgages were typically used by prime borrowers buying large houses relative to their income.

Mortgages of this sort create a strong incentive to refinance at the moment when required payments increase. Anticipating that creditworthy borrowers will refinance, mortgage lenders set high rates for those who do not. In an environment with fully rational and time-consistent borrowers and lenders, and no foreclosure externalities, this structure can be a good approximation to the solution of an optimal dynamic contracting problem (Piskorski and Tchistyi 2010, 2011). However, it can create several problems if these assumptions fail. First, borrowers with present-biased preferences may borrow and consume too much when offered larger mortgages (Ghent 2011, Mian and Sufi 2009). Second, unsophisticated borrowers who fail to refinance when they can do so will cross-subsidize more sophisticated borrowers, the problem identified by Miles (2004). Third, the system relies on the availability of refinancing. It breaks down when house prices fall and credit conditions deteriorate, and in these circumstances lenders may have to protect their interests by foreclosing. Thus the new mortgages of the 2000s are similar to the five-year balloon mortgages of the 1920s in their potential to generate economically damaging foreclosure waves. ${ }^{11}$

\section{Mortgage modification}

There is a great deal of concern about the high level of foreclosures since 2007. Some observers argue that given the loss of value in foreclosure, private lenders should slow foreclosures, or modify mortgages to reduce payments for a period of time, or even write down principal. An obvious objection is that if this were optimal for lenders, they would do it voluntarily. This can be countered in two ways.

A first argument is that securitized mortgages create conflicts of interest between mortgage servicers and ultimate investors; servicers bear more of the costs of modification, while investors receive more of the benefits, and this agency problem causes insufficient modification. Several recent papers compare modification rates and outcomes for securitized and directly held mortgages (Adelino et al. 2009, Agarwal et al. 2011, Foote et al. 2010, Piskorski et al. 2011).

A second argument is that negative externalities from foreclosures make the socially

\footnotetext{
${ }^{11}$ Corbae and Quintin (2010) calibrate a dynamic equilibrium model that captures this effect. Foote et al. (2012) point out that the decline in short-term Treasury bill rates during the financial crisis offset the increase in credit spreads caused by mortgage rate resets; however, it is still the case that rate resets prevented borrowers from benefiting from falling interest rates as they would have done if they had taken out plain-vanilla ARMs.
} 
optimal foreclosure rate lower than the privately optimal one. Mian et al. (2011) argue that US states that slow down foreclosures have recently performed better than those that allow rapid foreclosures; Gerardi et al. (2011) counter that slower foreclosures still take place eventually, generating the same or perhaps even greater external effects as houses are occupied for longer periods of time by distressed owners.

Whatever the ultimate outcome of this debate, it is clear that mortgage modification is much more costly - and perhaps prohibitively so - if undistressed borrowers who would otherwise pay their mortgages in full manage to obtain modification (Mayer et al. 2011). To avoid this, White (2009) suggests using the bankruptcy courts, allowing bankruptcy judges to modify mortgages in bankruptcy when this would be in the interest of mortgage holders. Congress discussed this as a retroactive measure ("cramdown") during the global financial crisis, but ultimately rejected such an ex post alteration of mortgage contracts. However, it may well make sense as a standard feature of future mortgages.

Whether mortgages are modified by lenders or by bankruptcy judges, an important issue is how to structure such modifications to minimize the probability of subsequent re-default. Das (2011) argues that principal reduction is most effective in this regard, and Doviak and MacDonald (2011) and Haughwout et al. (2010) provide supporting empirical evidence for this claim. ${ }^{12}$

There is also room for policy to reduce the externalities created by those foreclosures that do occur. To the extent that externalities result from vacant properties, it is appealing to try to rent out foreclosed homes rather than selling them to new homeowners. The US government is actively exploring ways to encourage such transitions from owner occupancy to rental housing. This is consistent with a new appreciation of the economic advantages of a vibrant rental sector in residential real estate.

\section{Mortgage form}

US borrowers and regulators retain a strong attachment to long-term fixed-rate mortgages with minimal prepayment penalties. These traditional FRMs have an overwhelming market share, especially after the extremely poor performance of complex adjustable-rate mortgages that were issued during the credit boom of the 2000s. The US system will continue to rely primarily on FRMs unless a catastrophic increase in inflation volatility makes them unaffordable.

The popularity of FRMs does not, however, justify subsidizing these mortgages through government intervention. As Lea and Sanders (2011) point out, countries with a greater reliance on ARMs have just as high homeownership rates as the US, and have done no worse in the recent downturn. ARMs have the advantage that lower interest rates reduce

\footnotetext{
${ }^{12}$ Edmans (2010) proposes a variant of principal reduction, structured as a cash payment to a borrower at mortgage maturity if all payments are made, and therefore not requiring any modification of the original mortgage terms. Mulligan (2010) criticizes federal mortgage modification programs for favoring interest reductions over principal reductions and for effectively increasing marginal income tax rates.
} 
defaults even when house price declines prevent mortgage borrowers from refinancing. And regulation can limit the complexity of ARMs without favoring FRMs.

Beyond this, economists have suggested several alternative mortgage forms that have attractive properties relative to standard FRMs and ARMs. First, an automatically refinancing FRM with no home equity extraction would address several problems that behavioral economists have highlighted with the conventional FRM. By automatically lowering required monthly payments when long-term nominal interest rates decline sufficiently, such a mortgage would eliminate refinancing costs, refinancing mistakes, and the temptation to deplete home equity at refinancing dates. Second, an inflation-indexed FRM, whose nominal payments vary in proportion to the price level (not the inflation rate or the nominal interest rate), would eliminate the inflation sensitivity of a nominal FRM without creating the instability of payment streams implied by an ARM. Third, a compromise between an ARM and a FRM could be constructed by gradually adjusting both nominal payments and the nominal principal balance in response to variation in short-term nominal interest rates. Such a compromise mortgage would be less inflation-sensitive than a conventional FRM and would have more stable payments than a conventional ARM.

More radically, some economists have advocated mortgages with principal balances that automatically adjust to the regional level of house prices (Shiller et al. 2011). This transfers house price risk from borrowers to lenders without relying on costly foreclosures to do so. ${ }^{13}$

\section{Consumer financial protection}

A related aspect of mortgage policy is regulation to ensure that borrowers, who are often financially unsophisticated, understand the choices they are offered and the fees that go along with them. Consumer financial regulation can take several forms surveyed by Campbell et al. (2011b).

First, regulation can simplify cost comparison of alternative mortgages, in the spirit of the 1968 Truth in Lending Act (TILA). One way to do this, suggested by Thaler and Sunstein (2008, Chapter 8), is to require that mortgage terms be made available electronically in standardized form to permit the development of online sites for comparison shopping. If housing tenure and prepayment data were also made available, more realistic cost comparisons could be based on historical average behavior, possibly for subgroups of the population, rather than on arbitrary assumptions such as the standard assumption that a mortgage is held to maturity.

Second, regulation can facilitate risk evaluation. In this regard it is key to offer households measures of risk as well as expected cost. Standard annual percentage rate (APR)

\footnotetext{
${ }^{13}$ There is a debate about whether homeowners should wish to lay off house price risk; Sinai and Souleles (2005) argue that they should not, because houses provide a known stream of housing services to long-term residents of an area and therefore insure their housing consumption against fluctuations in rents. However, this motivation for bearing house price risk does not apply to homeowners who plan to downsize, or to move to a distant location whose house prices are uncorrelated with their current location.
} 
calculations are helpful for comparing mortgages with similar risks, but not for comparing FRMs with ARMs, or for comparing ARMs with different initial fixed-rate periods, interest rate caps, and other complex features.

Third, regulation can promote standard mortgages. The case for doing this is that one or two standard mortgages may be reasonable choices for most households; if these mortgages are offered as a default option, many households will choose them and this may reduce the incidence of financial mistakes. The existence of standard mortgages also simplifies the task of cost comparison, since households can concentrate on standard mortgage terms rather than considering a vast array of special features. Woodward (2004) and Woodward and Hall (2012) present evidence that simple mortgage forms are associated with lower fees, particularly for less sophisticated borrowers.

In the past, US government sponsorship of the GSEs subsidized long-term nominal FRMs and helped them become de facto standard mortgages. The disadvantages of this approach have been discussed above. A more explicit regulatory policy favoring certain mortgages, for example by lowering capital requirements on banks holding them, or by requiring consumers to qualify for non-standard mortgages, would be a preferable alternative.

A fourth response to the problems consumers face in choosing mortgage products is to regulate the mortgage origination process. The Safe Mortgage Licensing Act of 2008 aims to establish minimum state standards for licensing mortgage originators. A more drastic approach would be to establish a fiduciary duty for mortgage brokers - that is, a legal duty that they use their best judgment in acting in the best interest of borrowers.

Given the limitations of existing mortgage contracts, it is important that regulation of mortgages should not be so heavy-handed that it precludes experimentation with new ideas. One possible role for the Consumer Financial Protection Bureau is to encourage small-scale experimentation with promising new mortgage forms. Consumer financial protection may also help constructive mortgage innovation indirectly, by reducing the cross-subsidies from naive to sophisticated borrowers that help to entrench confusing but commonly used forms of mortgages.

\section{Mortgage funding}

The funding model that developed in the US during the 1990s and 2000s has become dependent on a level of government intervention that is probably unsustainable. The GSEs have been in government conservatorship since September 2008, but they continue to hold large mortgage portfolios and to provide credit guarantees. There is consensus among many economists that a way must be found to restore private funding of mortgages with less reliance on taxpayer guarantees. ${ }^{14}$

Under these circumstances I agree with Lea (2011) that it is wise to look overseas to see

\footnotetext{
${ }^{14}$ See for example Acharya et al (2011), Baily (2011), Fuster and Vickery (2012), Jaffee and Quigley (2011), and US Treasury and Department of Housing and Urban Development (2011).
} 
if lessons from foreign markets can be applied to the US. A particularly promising model is the Danish mortgage system, because Denmark has traditionally used FRMs with no prepayment penalties, much like those favored in the US, and because the Danish system proved relatively stable even during the global financial crisis (Gyntelberg et al. 2012).

The Danish model has several appealing features. First, mortgages are funded using callable covered bonds with strict limits on maturity transformation. As mortgage demand has shifted towards shorter-term bonds in the last few years, mortgage bond maturities have declined in parallel. The use of covered bonds exposes Danish mortgage lenders to credit risk, which has desirable incentive effects, while interest-rate risk is transferred away from deposit-financed institutions and towards long-term investors who are better able to bear it.

Second, the Danish system treats movers and continuing homeowners equally, by allowing movers either to buy back mortgage bonds in the market or to pass their mortgages on to new homeowners when rates increase. These provisions eliminate the effects of idiosyncratic moving uncertainty on individual welfare, and an important source of aggregate uncertainty in pricing mortgage bonds. The ability of homeowners to effectively refinance by buying mortgage bonds also provides a source of liquidity for the mortgage market in a crisis; if investors dump mortgage bonds, homeowners can buy them just as companies can buy back their stock during a market crash.

Third, the Danish system constructs large, nationally diversified mortgage pools that therefore are relatively liquid because there is little incentive to obtain private information about the underlying mortgages.

Finally, defaults and foreclosures have been a less serious problem in Denmark, despite a large recent decline in house prices, because of a combination of strict regulation, conservative underwriting incentivized by the covered bond system, and the use of recourse mortgages. During the financial crisis, the central bank did have to intervene to ensure adequate funding of mortgage lenders, but the degree of intervention appears to have been much smaller than was required in the US.

The US has had some limited experience with covered bonds, notably those issued by Washington Mutual (Bergstresser et al. 2009). WaMu's covered bonds paid off in full, despite the originator's bankruptcy in September 2008. Congress has recently considered legislation to provide a statutory framework for covered bonds in the US. One challenge is how to reconcile the protection of covered bondholders with the obligation of the Federal Deposit Insurance Corporation (FDIC) to resolve failed banks at minimum cost to taxpayers. ${ }^{15}$ In addition, since covered bonds keep credit risk on the books of mortgage originators, they

\footnotetext{
${ }^{15}$ See Federal Deposit Insurance Corporation (2011) and US Treasury (2008) for recent statements on covered bond design issues in the US context. The key issue is whether, upon the failure of a mortgage originator, the collateral for covered bonds is sequestered for the life of the bonds, or whether the FDIC has the right to pay off the covered bonds at par and reclaim the collateral as it resolves the failed originator.
} 
imply that financial institutions are exposed to the risk of an aggregate house price decline. If the US moves towards greater use of covered bonds, it may be useful to develop derivatives markets to allow US financial institutions to hedge their aggregate house price exposure.

\section{Conclusion}

There is a strong public interest in an efficient and stable housing finance system. An unregulated system may generate inefficiencies in several ways, including negative externalities from foreclosures, financial system instability, and high costs for unsophisticated borrowers. The US has a complex regulatory and tax regime for mortgages that has evolved with the primary goal of promoting homeownership, but is not obviously successful in this regard. This regime has many unintended consequences that have become particularly obvious during the recent financial crisis.

In the long run, it may be possible for economists to solve the optimal dynamic contracting problem and recommend an ideal mortgage system on this basis. At this time, however, it is too hard to do this exercise without assuming away the market failures that justify mortgage regulation in the first place. For now, mortgage market design must proceed in a more ad hoc and flexible fashion, learning from international experience - for example, from the Danish implementation of the European covered bonds system - and integrating insights from different fields including urban economics, asset pricing, behavioral finance, financial intermediation, and macroeconomics. 


\section{References}

Acharya, V., Richardson, M., van Nieuwerburgh, S., and White, L. (2011) Guaranteed to Fail: Fannie Mae, Freddie Mac, and the Debacle of Mortgage Finance, Princeton University Press, Princeton, NJ.

Adelino, M., Gerardi, K., and Willen, P. (2009), Renegotiating home mortgages: evidence from the subprime crisis, unpublished paper, Federal Reserve Bank of Boston.

Agarwal, S., Amromin, G., Ben-David, I., Chomsisengphet, S., and Evanoff, D. (2011), The role of securitization in mortgage renegotiation, Journal of Financial Economics 102, $559-578$.

Amromin, G., Huang, J., Sialm, C., and Zhong, E. (2011), Complex mortgages, NBER working paper 17315 .

Anenberg, E., and Kung, E. (2012), Estimates of the size and source of price declines due to nearby foreclosures, unpublished paper, Federal Reserve Board of Governors, Duke University.

Baily, M. (2011) The Future of Housing Finance: Restructuring the U.S. Residential Mortgage Market, Brookings Institution Press, Washington, DC.

Bajari, P., Chu, C.S., and Park, M. (2008), An empirical model of subprime mortgage default from 2000 to 2007, NBER working paper 14625.

Bergstresser, D., Greenwood, R., and Quinn, J. (2009) Washington Mutual's Covered Bonds, Harvard Business School Case 9-209-093, Harvard Business School Publishing, Boston, MA.

Bhutta, N., Dokko, J., and Shan, H. (2010), The depth of negative equity and mortgage default decisions, FEDS Working Paper 2010-35, Federal Reserve Board.

Brueckner, J. (1994) Borrower mobility, adverse selection, and mortgage points, Journal of Financial Intermediation 3, 416-441.

Bucks, B., and Pence, K. (2008) Do borrowers know their mortgage terms?, Journal of Urban Economics 64, 218-233.

Campbell, J. (2006) Household finance, Journal of Finance 61, 1553-1604.

Campbell, J., and Cocco, J. (2003) Household risk management and optimal mortgage choice, Quarterly Journal of Economics 118, 1449-1494.

Campbell, J., and Cocco, J. (2012), A model of mortgage default, unpublished paper, Harvard University, London Business School. 
Campbell, J., Giglio, S., and Pathak, P. (2011a) Forced sales and house prices, American Economic Review 101, 2108-2131.

Campbell, J., Jackson, H., Madrian, B., and Tufano, P. (2011b) Consumer financial protection, Journal of Economic Perspectives 25(1), 91-114.

Chen, H., Michaux, M., and Roussanov, N. (2011), Houses as ATMs? Mortgage refinancing and macroeconomic uncertainty, unpublished paper, MIT Sloan, USC, Wharton.

Committee on the Global Financial System (2006) Housing finance in the global financial market, CGFS paper 26, Bank for International Settlements.

Corbae, D., and Quintin, E. (2010), Mortgage innovation and the foreclosure boom, unpublished paper, University of Texas, University of Wisconsin.

Das, S. (2011) The principal principle: optimal modification of distressed home loans, forthcoming Journal of Financial and Quantitative Analysis.

Deng, Y., Quigley, J., and Van Order, R. (2000) Mortgage terminations, heterogeneity and the exercise of mortgage options, Econometrica 68(2), 275-307.

DiPasquale, D., and Glaeser, E. (1999) Incentives and social capital: are homeowners better citizens?, Journal of Urban Economics 45, 354-384.

Doviak, E., and MacDonald, S. (2009), Who enters the foreclosure process?, unpublished paper, City University of New York.

Edmans, A. (2010), The responsible homeowner reward: an incentive-based solution to strategic mortgage default, unpublished paper, University of Pennsylvania.

Ellen, I., Lacoe, J., and Sharygin, C. (2011), Do foreclosures cause crime?, unpublished paper, New York University.

Elul, R., Souleles, N., Chomsisengphet, S., Glennon, D., and Hunt, R. (2010) What 'triggers' mortgage default?, American Economic Review Papers and Proceedings 100, 490 - 494.

Federal Deposit Insurance Corporation (2011), Statement on legislative proposals to create a covered bond market in the United States, financialservices.house.gov/media/pdf/031111fdic.pdf.

Foote, C., Gerardi, K., and Willen, P. (2008) Negative equity and foreclosure: theory and evidence, Journal of Urban Economics 64, 234 - 245.

Foote, C., Gerardi, K., and Willen, P. (2012), Why did so many people make so many ex post bad decisions? The causes of the foreclosure crisis, unpublished paper, Federal Reserve Bank of Boston.

Foote, C., Gerardi, K., Goette, L., and Willen, P. (2010) Reducing foreclosures: no easy answers, NBER Macroeconomics Annual 2009, 89-138. 
Fuster, A., and Vickery, J. (2012), Securitization and the fixed-rate mortgage, unpublished paper, Federal Reserve Bank of New York.

Gabaix, X., and Laibson, D. (2006) Shrouded attributes, consumer myopia, and information suppression in competitive markets, Quarterly Journal of Economics 121, 505-540.

Gerardi, K., Lambie-Hanson, L., and Willen, P. (2011), Do borrower rights improve borrower outcomes? Evidence from the foreclosure process, NBER Working Paper 17666.

Gerardi, K., Rosenblatt, E., Willen, P., and Yao, V. (2012), Foreclosure externalities: some new evidence, unpublished paper, Federal Reserve Bank of Atlanta, Federal Reserve Bank of Boston, Fannie Mae.

Gerardi, K., Rosen, H., and Willen, P. (2010) The impact of deregulation and financial innovation on consumers: the case of the mortgage market, Journal of Finance 65, 333-360.

Ghent, A., and Kudlyak, M. (2011) Recourse and residential mortgage default: evidence from U.S. states, Review of Financial Studies 24, 3139-3186.

Ghent, A. (2011), Subprime mortgages, mortgage choice, and hyperbolic discounting, unpublished paper, Zicklin School of Business.

Glaeser, E. (2011) Triumph of the City: How Our Greatest Invention Makes Us Richer, Smarter, Greener, Healthier, and Happier, Penguin Press, New York, NY.

Glaeser, E., and Shapiro, J. (2003) The benefits of the home mortgage interest deduction, Tax Policy and the Economy 17, 37-82.

Goodstein, R., Hanouna, P., Ramirez, C. and Stahel, C. (2011), Are foreclosures contagious?, unpublished paper, FDIC, Villanova University, George Mason University.

Grebler, L., Blank, D., and Winnick, L. (1956) Capital Formation in Residential Real Estate: Trends and Prospects, Princeton University Press, Princeton, NJ.

Guiso, L., Sapienza, P., and Zingales, L. (2009), Moral and social constraints to strategic default on mortgages, NBER working paper 15145.

Gyntelberg, J., Kjeldsen, K., Baekmand Nielsen, M., and Persson, M. (2012). The 2008 financial crisis and the Danish mortgage market, in: A. Bardhan, R.H. Edelstein, and C.A. Kroll (eds.) Global Housing Markets: Crises, Policies, and Institutions, John Wiley, pp. 53-68.

Haughwout, A., Okah, A., and Tracy, J. (2010), Second chances: subprime mortgage modification and re-default, unpublished paper, Federal Reserve Bank of New York.

Immergluck, D., and Smith, G. (2006) The impact of single-family mortgage foreclosures on neighborhood crime, Housing Studies 21, 851-66. 
International Monetary Fund (2011). Housing finance and financial stability - back to basics?, in: Global Financial Stability Report, April 2011: Durable Financial Stability - Getting There from Here, International Monetary Fund, Washington, DC, pp. 111142.

Jaffee, D., and Quigley, J. (2011), The future of the government sponsored enterprises: the role for government in the U.S. mortgage market, NBER working paper 17685.

Johnson, K., and Li, G. (2011), Are adjustable-rate mortgage borrowers borrowing constrained?, FEDS Working Paper 2011-21, Federal Reserve Board, Washington, DC.

Keys, B., Mukherjee, T., Seru, A., and Vig, V. (2010) Did securitization lead to lax screening? Evidence from subprime loans, Quarterly Journal of Economics 125, 307-362.

Keys, B., Seru, A., and Vig, V. (2012) Lender screening and the role of securitization: evidence from prime and subprime mortgage markets, Review of Financial Studies 25, 2071-2108.

Khandani, A., Lo, A., and Merton, R. (2009), Systemic risk and the refinancing ratchet effect, NBER Working Paper 15362.

Koijen, R., Van Hemert, O., and Van Nieuwerburgh, S. (2009) Mortgage timing, Journal of Financial Economics 93, 292-324.

Laibson, D. (1997) Golden eggs and hyperbolic discounting, Quarterly Journal of Economics 112, 443-477.

Lea, M. (2011). Alternative forms of mortgage finance: what can we learn from other countries?, in: N. Retsinas and E. Belsky (eds.), Moving Forward: The Future of Consumer Credit and Mortgage Finance, Joint Center for Housing Studies, Harvard University, Cambridge, MA, and Brookings Institution Press, Washington, DC, pp. $118-149$.

Lea, M., and Sanders, A. (2011) Government policy and the fixed-rate mortgage, Annual Reviews of Financial Economics 3, 223-234.

Li, W., White, M., and Zhu, N. (2010), Did bankruptcy reform cause mortgage default to rise?, NBER Working Paper 15968.

Lin, Z., Rosenblatt, E., and Yao, V. (2009) Spillover effects of foreclosures on neighborhood property values, Journal of Real Estate Finance and Economics 38, 387-407.

Mayer, C., Morrison, E., Piskorski, T., and Gupta, A. (2011), Mortgage modification and strategic behavior: evidence from a legal settlement with Countrywide, NBER Working Paper 17065.

Mayer, C., Pence, K., and Sherlund, S. (2009) The rise in mortgage defaults, Journal of Economic Perspectives 23(1), 27-50. 
Melzer, B. (2011), Mortgage debt overhang: reduced investment by homeowners with negative equity, unpublished paper, Northwestern University.

Mian, A., and Sufi, A. (2009) The consequences of mortgage credit expansion: evidence from the U.S. mortgage default crisis, Quarterly Journal of Economics 124, 1449-1496.

Mian, A., Sufi, A., and Trebbi, F. (2011), Foreclosures, house prices, and the real economy, NBER working paper 16685.

Miles, D. (2004) The UK Mortgage Market: Taking a Longer-term View, HM Treasury, London, UK.

Mitman, K. (2011), The macroeconomic effects of bankruptcy and foreclosure policies, unpublished paper, Penn Institute For Economic Research.

Morton, J., (1956) Urban Mortgage Lending: Comparative Markets and Experience, Princeton University Press, Princeton, NJ.

Mulligan, C. (2010), Foreclosures, enforcement, and collections under the federal mortgage modification guidelines, unpublished paper, University of Chicago.

Piskorski, T., Seru A., and Vig, V. (2011) Securitization and distressed loan renegotiation: evidence from the subprime mortgage crisis, Journal of Financial Economics 97, 369397.

Piskorski, T., and Tchistyi, A. (2010) Optimal mortgage design, Review of Financial Studies 23, 3098-3140.

Piskorski, T., and Tchistyi, A. (2011) Stochastic house appreciation and optimal mortgage lending, Review of Financial Studies 24, 1407-1446.

Scanlon, K., Lunde, J., and Whitehead, C. (2008) Mortgage product innovation in advanced economies: more choice, more risk, European Journal of Housing Policy 8, 109-131.

Schwartz, A. (2006), Household refinancing behavior in fixed rate mortgages, unpublished paper, Harvard University.

Shiller, R., Wojakowski, R., Ebrahim, M.S., and Shackleton, M. (2011), Continuous workout mortgages, NBER Working Paper 17007.

Sinai, T., and Souleles, N. (2005) Owner-occupied housing as a hedge against rent risk, Quarterly Journal of Economics 120(2), 763-789.

Stanton, R., and Wallace, N. (1998) Mortgage choice: what's the point?, Real Estate Economics 26, 173-205.

Thaler, R., and Sunstein, C. (2008) Nudge: Improving Decisions About Health, Wealth, and Happiness, Yale University Press, New Haven, CT. 
U.S. Treasury (2008) Best practices for residential covered bonds, http://www.treasury.gov/about/

organizational-structure/offices/General-Counsel/Documents/USCoveredBondBestPractices.pdf.

U.S. Treasury (2009) Making home affordable: updated detailed program description, http://www.treasury.gov/press-center/press-releases/Pages/20092181117388144.aspx.

U.S. Treasury and Department of Housing and Urban Development (2011) Reforming America's Housing Market: A Report to Congress, Washington, DC.

Warnock, V., and Warnock, F. (2008) Markets and housing finance, Journal of Housing Economics 17, 239-251.

White, M. (2009) Bankruptcy: Past puzzles, recent reforms, and the mortgage crisis, American Law and Economics Review 11, 1-23.

Woodward, S. (2004), Consumer confusion in the mortgage market, Sand Hill Econometrics unpublished paper, available online at http://www.sandhillecon.com.

Woodward, S., and Hall, R. (2012) Diagnosing consumer confusion and sub-optimal shopping effort: theory and mortgage market evidence, American Economic Review, forthcoming. 


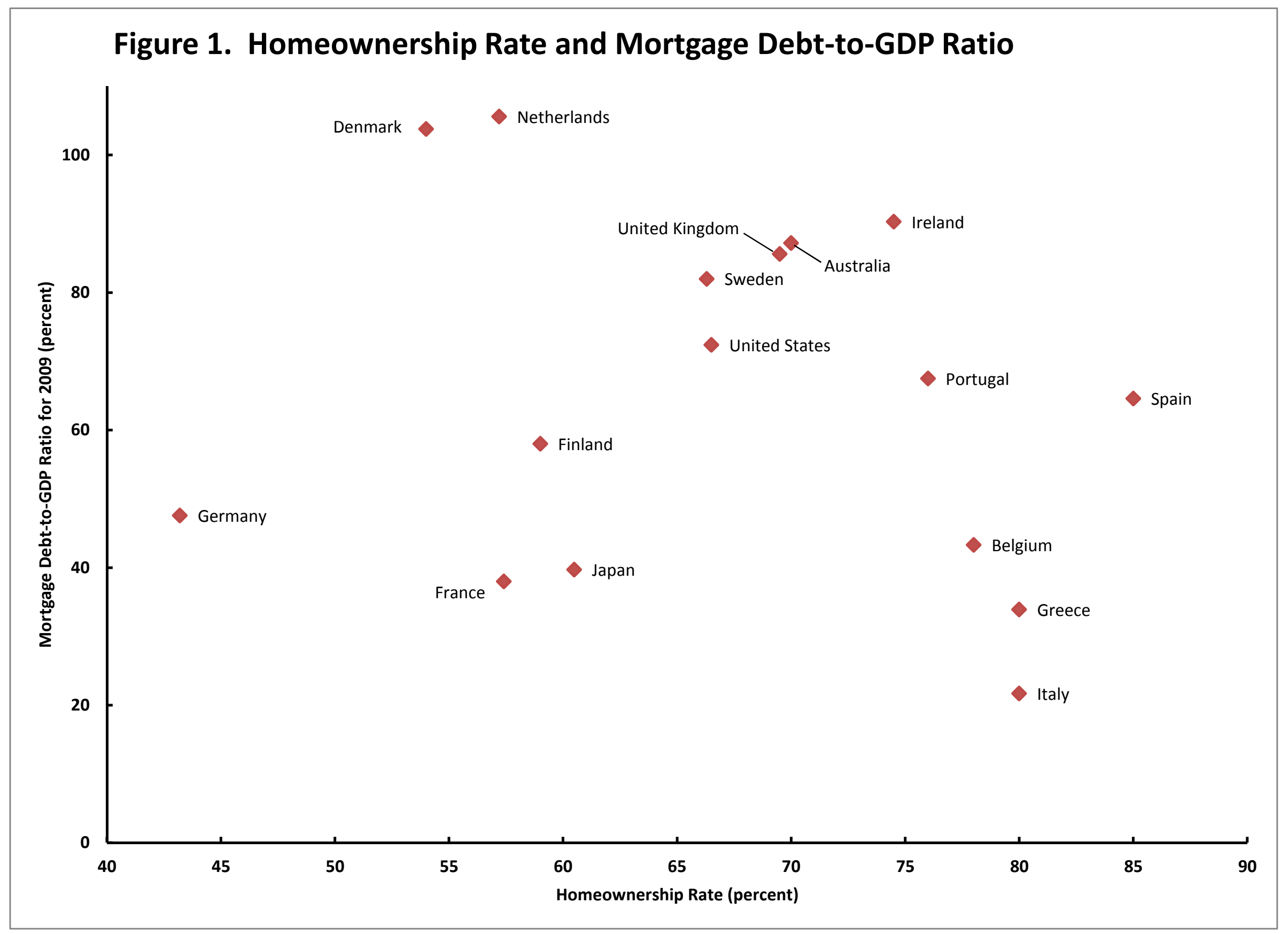




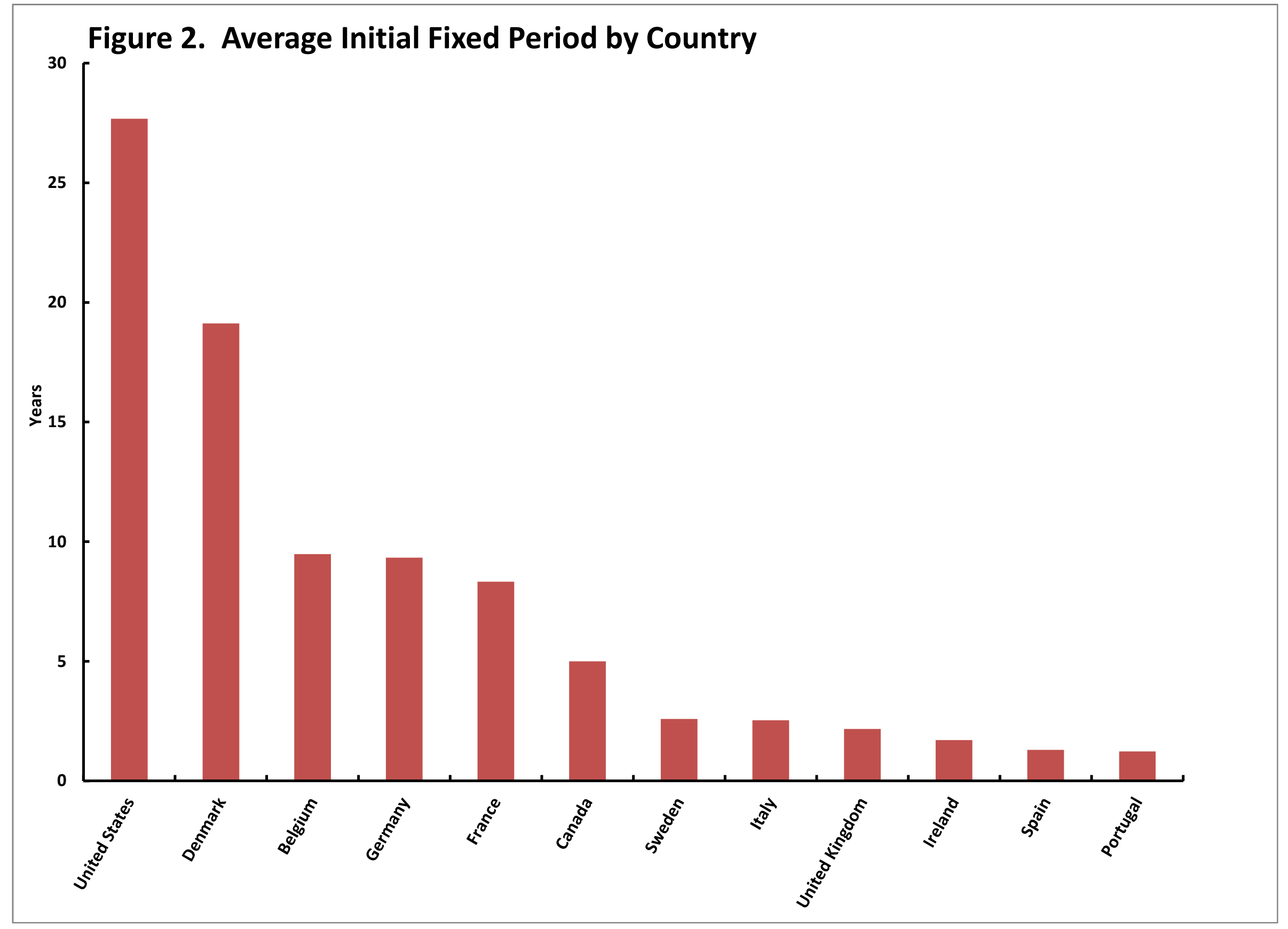




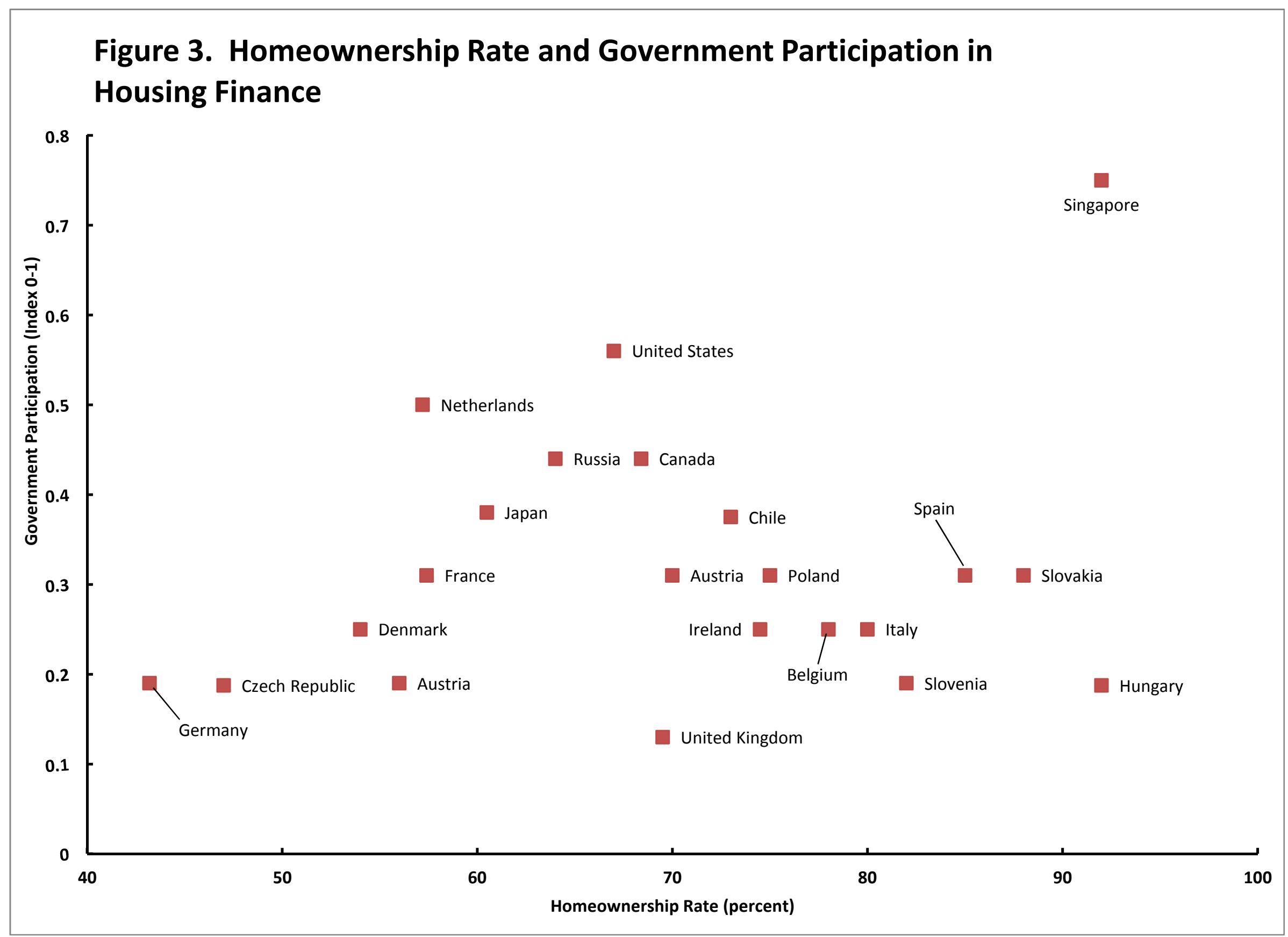




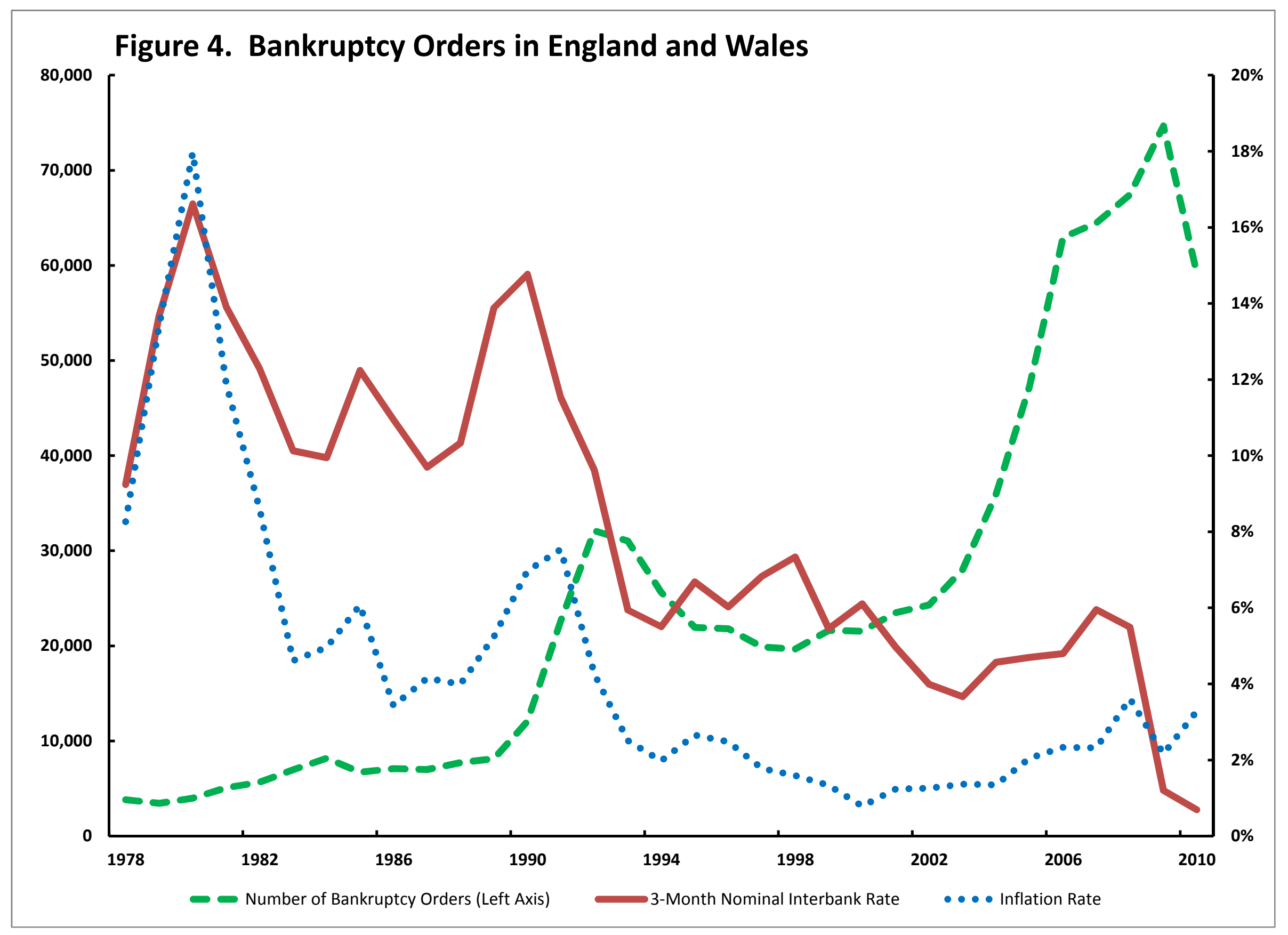




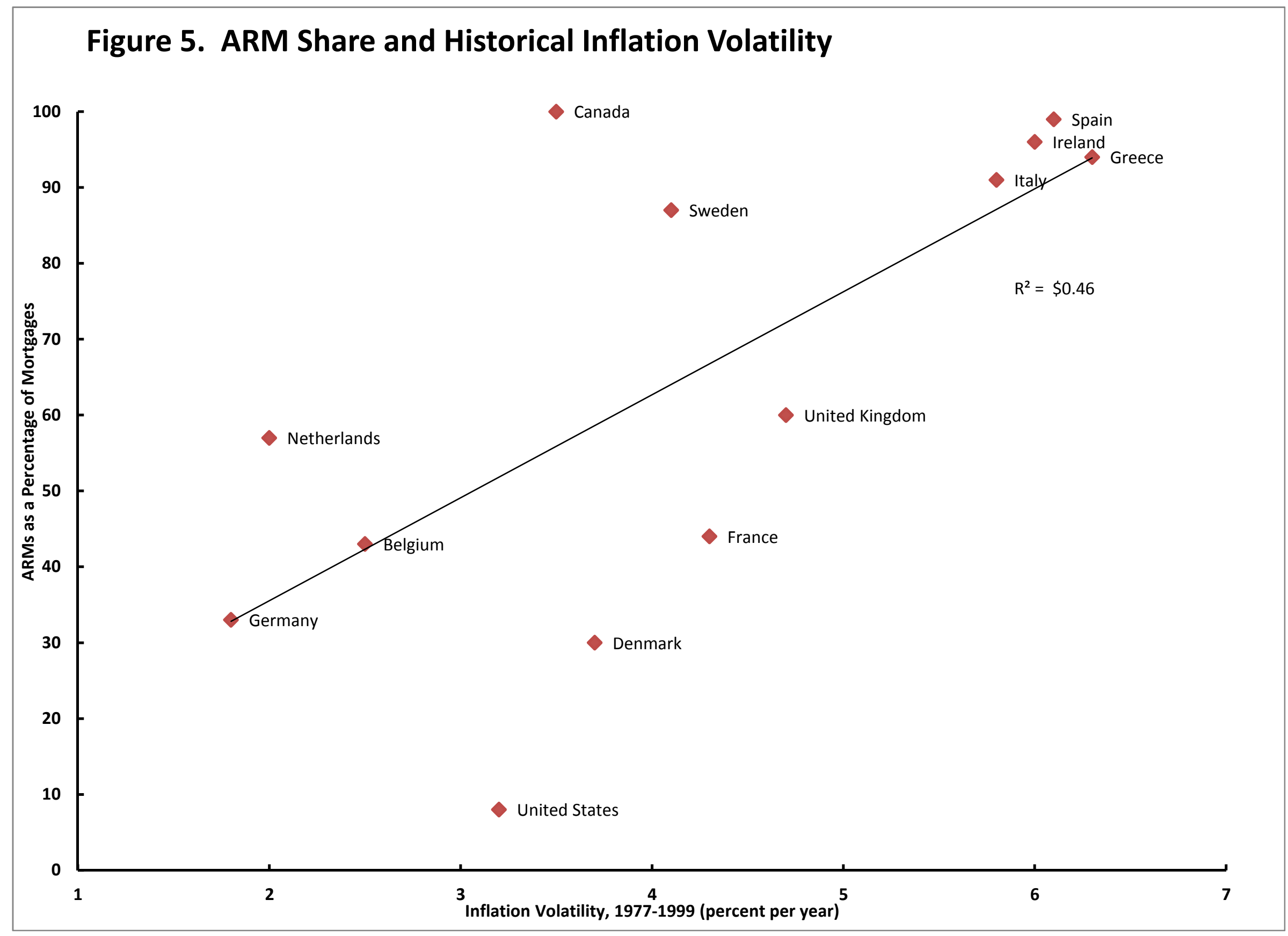

